\title{
Peningkatan Profesionalisme Guru Pendidikan Agama Katolik dalam Pengembangan Bahan Ajar Lembar Kerja Siswa (LKS) Melalui Supervisi Klinis Pengawas di Sekolah Dasar Binaan Kota Mataram
}

\author{
Maksimilianus Naben \\ Pengawas Kantor Kementerian Agama, Kota Mataram \\ *Corresponding Author. Email: noemuti11@gmail.com
}

\begin{abstract}
This study aims to increase the professionalism of Catholic religious education teachers in the development of student worksheets (LKS) teaching materials through clinical supervision of supervisors at the elementary schools built in the city of Mataram. This research method uses Supervision Action Research (PTKp). The subjects of this research were 17 teachers of Catholic religious education in the target area of Mataram city. The research instrument used a questionnaire and an observation sheet. The data collected were analyzed qualitatively and quantitatively. The results of this study indicate that coaching in an effort to increase the professionalism of Catholic religious education teachers in developing teaching materials for the preparation of Student Worksheets (LKS) through clinical supervision by supervisors shows a significant increase in each cycle. In addition, the activities in each coaching show that all Catholic religious education teachers can increase their professionalism in every aspect.
\end{abstract}

Abstrak: Penelitian ini bertujuan untuk meningkatkan profesionalisme guru pendidikan agama katolik dalam pengembangan bahan ajar lembar kerja siswa (LKS) melalui supervisi klinis pengawas di sekolah dasar binaan wilayah kota Mataram. Metode penelitian ini menggunakan Peneltian Tindakan Kepengawasan (PTKp). Subjek penelitian ini adalah adalah guru-guru pendidikan agama Katolik wilayah binaan kota Mataram yang berjumlah 17 orang. Instrumen penelitian ini menggunakan angket dan lembar observasi. Data yang terkumpul dianalisis secara kualitatif dan kuantitatif. Hasil penelitian ini menunjukkan bahwa pembinaan dalam upaya meningkatkan profesionalisme guru pendidikan agama Katolik dalam mengembangkan bahan ajar penyusunan Lembar Kerja Siswa (LKS) melalui supervisi klinis oleh pengawas menunjukkan peningkatan yang signifikan pada setiap siklus. Selain itu, aktivitas dalam setiap pembinaan menunjukkan bahwa semua guru pendidikan agama katolik dapat meningkat profesionalismenya dalam setiap aspek.

\section{Article History}

Received: 12-11-2021

Revised: 09-12-2021

Accepted: 21-12-2021

Published: 07-01-2022

\section{Key Words:}

Teacher Professionalism, Teaching Materials, Student Worksheets, Clinical Supervision.

\section{Sejarah Artikel \\ Diterima: 12-11-2021 \\ Direvisi: 09-12-2021 \\ Disetujui: 21-12-2021 \\ Diterbitkan: 07-01-2022}

\section{Kata Kunci:}

Profesionalisme Guru, Bahan Ajar, Lembar Kerja Siswa, Supervisi Klinis.

How to Cite: Naben, M. (2022). Peningkatan Profesionalisme Guru Pendidikan Agama Katolik dalam Pengembangan Bahan Ajar Lembar Kerja Siswa (LKS) Melalui Supervisi Klinis Pengawas di Sekolah Dasar Binaan Kota Mataram. Jurnal Paedagogy, 9(1), 62-68. doi:https://doi.org/10.33394/jp.v9i1.4668

\section{Pendahuluan}

Upaya mereformasi pendidikan selalu dihadapkan pada masalah tuntutan guru yang profesional. Guru dituntut memiliki banyak kemampuan, mempunyai banyak ide, kritis, seorang intelektual yang mampu menyelesaikan persoalan yang dihadapi oleh siswa. Selain itu guru diharapkan mampu mengajar dengan baik, kreatif, demokratis, sehingga mampu membentuk peserta didik menjadi pribadi yang cerdas, berbudaya, berkarakter, beriman dan bertaqwa kepada Tuhan Yang Maha Esa (Purnamaraya, 2019; Wahyuni, 2021). Undangundang guru dan dosen No. 14 tahun 2005 mensyaratkan bahwa seorang guru harus memiliki kualifikasi minimal S1 dan beberapa kompetensi seperti: kompetensi kepribadian, pedagogik, dan spiritual. Benar dikatakan bahwa membicarakan guru sama dengan membicarakan 
persoalan rawan, karena berkaitan dengan cita-cita masa depan bangsa. Keberadaan guru selalu menjadi sorotan. Mengembangkan kualitas kehidupan sangat erat kaitannya dengan membangun kualitas pendidikan (Mujtahid, 2011). Sementara kualitas pendidikan sangat ditentukan oleh kualitas tenaga pendidik (guru) (Ramayulis, 2013). Meski guru bukan satusatunya instrument dalam dunia pendidikan, tetapi gurulah yang memegang peranan penting sekaligus sebagai ujung tombak sukses dan gagalnya pendidikan (Agung, 2014).

Paragraf di atas menunjukkan bahwa salah satu unsur utama dalam meningkatnya mutu pendidikan di Indonesia adalah mutu guru. Bahasa yang lebih modern untuk menegaskan guru yang bermutu adalah profesionalisme. Persoalan selanjutnya adalah bagaimana merumuskan jawaban definitif, tegas dan bertanggung jawab atas pertanyaanpertanyaan berikut ini. Bagaimana mengembangkan profesionlisme guru? Bagaimana mengukur keprofesionalan seorang guru? Bagaimana menetapkan standar profesionalisme dalam upaya mendukung guru berkualitas?. Potret kualifikasi guru di Indonesia berdasarkan data Departemen Pendidikan Nasional yang dikutip Habeahan (2006), menunjukkan guru yang layak mengajar hanya 50,7\% untuk jenjang SD; 65,1\% untuk SMP dan 67,1\% untuk SMA. Selain itu, dalam (Statistik Deskriptif Skor Mentah Per Mata Uji, Direktorat Tenaga Kependidikan, 2004) dikatakan rata-rata kompetensi guru tidak mencapai $50 \%$ seperti ditunjuk dalam tes umum guru TK-SD dan tes bidang studi guru SMP,SMA/SMK (Habeahan, 2006).

Kunci menjadikan pendidikan nasional bermutu dan menghasilkan sumber daya manusia yang berkualitas dan berdaya saing, terletak pada seorang guru (Rusman, 2014; Sagala, 2012). Oleh karena itu, perlu ditingkatkan kualitas dan martabat guru, karena tanpa guru yang berkualitas tidak mungkin kita mengharapkan sumber daya manusia yang berkualitas pula. Guru harus berkualitas agar mampu melaksanakan tugas sebagai guru dan menjadi teladan bagi peserta didik sehingga guru dituntut memiliki kompetensi kepribadian, kompetensi pedagogis, kompetensi spiritual (Islamuddin, 2021; Kamaruddin, 2021). Guru yang berkualitas mampu mempersiapkan peserta didik untuk memainkan peran mereka di dalam masyarakat sebagai warga negara yang dewasa dan bertanggung jawab (Zainudin, 2016; Sudiarti, 2017).

Beberapa masalah pokok berkaitan dengan profesionalisme guru dapat dikemukakan di sini antara lain: (1) Adanya kecenderungan melemahnya sikap profesionalisme guru dalam kaitan dengan mempersiapkan bahan ajar seperti: handout, modul, buku teks, lembar kerja siswa (LKS), model (maket), kelengkapan administrasi, metode, sumber, strategi, penilaian pembelajaran. (2). Supervisi terpadu kepala sekolah dan pengawas belum berdampak maksimal terhadap peningkatan kinerja profesional guru (3). Adanya penurunan kemampuan guru dalam pengembangan bahan ajar berakibat pada menurunnya nilai ujian akhir siswa pada sekolah dasar binaan di wilayah kota Mataram. (4) Masih banyak guru yang belum menekuni profesinya secara totalitas. (5) Belum optimalnya standar profesional guru sebagaimana tuntutan di negara maju, (6) Belum optimalnya guru dalam meningkatkan kualitas diri, (7) Belum maksimalnya pelaksanaan supervisi oleh pengawas (Makawimbang, 2013; Sahertian, 2010).

Hamalik (dalam Rusman, 2014) menjelaskan bahwa ciri seorang guru yang profesional adalah sebagai berikut: (1) Mampu merencanakan pembelajaran, (2) mampu mengelola program belajar mengajar, (3) mampu mengelola kelas, (4) mampu menggunakan media/sumber belajar, (5) mampu mengelola interaksi belajar mengajar, (5) mampu melaksanakan evaluasi belajar siswa. Medley dalam Depdikbud (1984) meninjau masalah efektifitas guru sebagai berikut: (1) memiliki pribadi kooperatif, daya tarik, penuh 
pertimbangan dan memiliki jiwa kepemimpinan. (2) menguasai metode mengajar yang baik, (3) memiliki tingkah laku yang baik saat mengajar, (4) menguasai berbagai kompetensi dalam mengajar. Bila mengacu pada konsep-konsep di atas, menjadi profesional adalah meramu kualitas dengan intergiritas, menjadi guru pforesional adalah keniscayaan. Karena ibarat sebuah laboratorium, seorang guru seperti ilmuwan yang sedang bereksperimen terhadap nasib anak manusia dan juga suatu bangsa.

Pendidikan Agama Katolik adalah usaha yang dilakukan secara terencana dan berkesinambungan dalam rangka mengembangkan kemampuan pada siswa untuk memperteguh iman dan ketakwaan kepada Tuhan Yang Maha Esa sesuai dengan agama Katolik, dengan tetap memperhatikan penghormatan terhadap agama lain dalam hubungan kerukunan antar umat beragama dalam masyarakat untuk mewujudkan persatuan nasional. Secara lebih tegas dapat dikatakan bahwa pendidikan agama Katolik di sekolah merupakan salah satu usaha untuk memampukan siswa berinteraksi (berkomunikasi), memahami, menggumuli dan menghayati iman. Dengan kemampuan berinteraksi antara pemahaman iman, pergumulan iman dan penghayatan iman itu diharapkan iman siswa semakin diperteguh. Pendidikan agama Katolik (PAKat) pada dasarnya bertujuan agar peserta didik memiliki kemampuan untuk membangun hidup yang semakin beriman. Membangun hidup beriman Kristiani berarti membangun kesetiaan pada Injil Yesus Kristus, yang memiliki keprihatinan tunggal, yakni Kerajaan Allah. Kerajaan Allah merupakan situasi dan peristiwa penyelamatan: situasi dan perjuangan untuk perdamaian dan keadilan, kebahagiaan dan kesejahteraan, persaudaraan dan kesetiaan, kelestarian lingkungan hidup, yang dirindukan oleh setiap orang dari pelbagai agama dan kepercayaan.

Fakta di lapangan menunjukkan bahwa masih ditemukan berbagai kendala dalam pelaksanaan pembelajaran pendidikan agama Katolik di sekolah-sekolah demi terwujudnya tujan pendidikan agama Katolik yang sesungguhnya. Salah satu persoalah mendasar adalah kualitas guru dalam penggelolaan pembelajaran Pendidikan agama Katolik. Kompetensi profesional guru merupakan salah satu faktor penentu meningkatnya mutu pendidikan khususnya pendidikan agama Katolik. Adapun tujuan penelitian ini adalah untuk meningkatkan profesionalisme guru pendidikan agama katolik dalam pengembangan bahan ajar lembar kerja siswa (LKS) melalui supervisi klinis pengawas di sekolah dasar binaan wilayah kota Mataram.

\section{Metode Penelitian}

Penelitian ini menggunakan Peneltian Tindakan Kepengawasan (PTKp) yang pelaksanaannya meliputi tahapan perencanaan (planning), tindakan (action), pengamatan (observation) dan refleksi (reflection) yang selanjutnya tahapan-tahapan tersebut dirangkai dalam suatu siklus kegiatan. Penelitian tindakan kelas ini dengan desain Arikunto (2014) sebagai berikut:

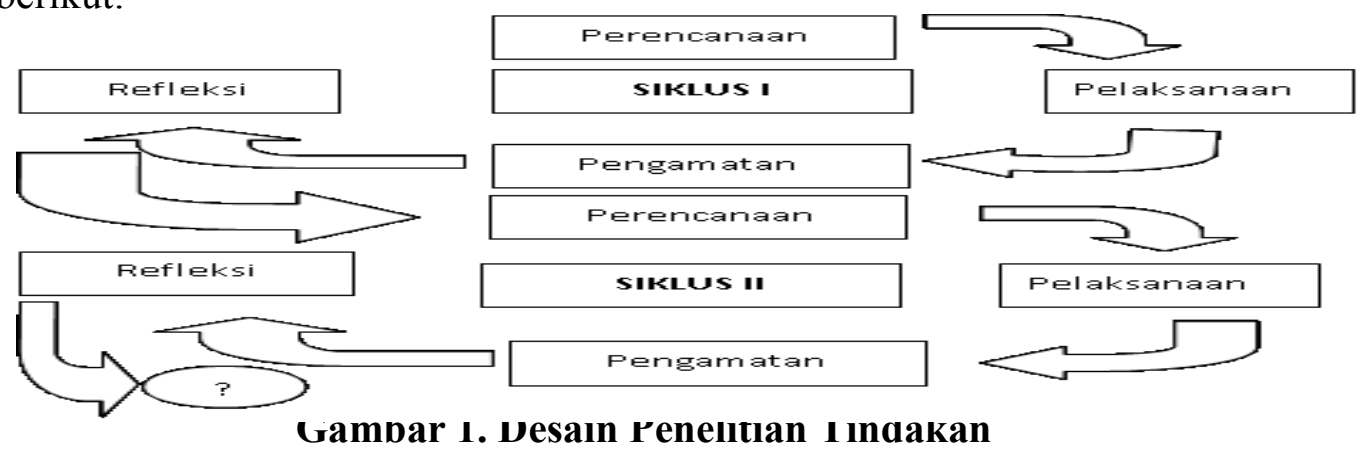


Subjek penelitian ini adalah adalah guru-guru pendidikan agama Katolik wilayah binaan kota Mataram yang berjumlah 17 orang. Instrumen penelitian ini menggunakan angket dan lembar observasi. Data yang terkumpul dianalisis secara kualitatif dan kuantitatif. Analisis kuantitatif digunakan untuk menghitung besarnya peningkatan profesionalisme guru pendidikan agama Katolik dalam mengembangkan bahan ajar menyusun Lembar Kerja Siswa (LKS) di sekolah dasar binaan wilayah kota Mataram melalui pembinaan pengawas pendidikan agama Katolik dengan menggunakan prosentasi (\%). Sedangkan teknik analisis kualitatif digunakan untuk memberikan gambaran hasil penelitian secara reduksi data, sajian deskriptif, dan penarikan simpulan.

\section{Hasil Penelitian dan Pembahasan}

Setelah dilaksanakan penelitian tindakan pada siklus I, II dan III maka hasilnya ditunjukkan sebagai berikut:

Tabel 1. Analisis Hasil Pembinaan Pengawas dalam Meningkatkan Profesionalisme Guru Pendidikan Agama Katolik dalam Pengembangan Bahan Ajar Penyusunan Lembar Kerja Siswa (LKS) Melalui Supervisi Klinis.

\begin{tabular}{|c|l|c|c|c|}
\hline No & \multicolumn{1}{|c|}{ Nama guru } & $\begin{array}{c}\text { Skor sebelum } \\
\text { Tindakan } \\
\text { Siklus I }\end{array}$ & $\begin{array}{c}\text { Skor } \\
\text { sebelum } \\
\text { Tindakan 1 } \\
\text { Siklus II }\end{array}$ & $\begin{array}{c}\text { Skor } \\
\text { sebelum } \\
\text { Tindakan 2 } \\
\text { Siklus III }\end{array}$ \\
\hline 1 & DH. Budi Santoso, S.Ag & 75 & 75 & 95 \\
\hline 2 & Lidia Veranika Tarukalo, S.Th & 60 & 70 & 80 \\
\hline 3 & Margaretta Riswanti, S.Ag. & 65 & 85 & 95 \\
\hline 4 & $\begin{array}{l}\text { I Made Nuryantho Norbertus, } \\
\text { S.Ag. }\end{array}$ & 60 & 70 & 75 \\
\hline 5 & Ludgardis Wuga, S.Ag. & 60 & 70 & 75 \\
\hline 6 & Sulistiyanti, S.Ag. & 50 & 75 & 80 \\
\hline 7 & Stefana Sadipun, A.Ma & 50 & 60 & 75 \\
\hline 8 & RR. Caecilia Sri Haryanti, A. & 75 & 85 & 95 \\
\hline 9 & Ma. Pd & & & 80 \\
\hline 10 & Elisabet Romanis, S.Ag. & 75 & 85 & 95 \\
\hline 11 & Maria Retnaningsih, S.Ag. & 60 & 60 & 80 \\
\hline 12 & Ni Nyoman Astini, S.Ag. & 75 & 75 & 85 \\
\hline 13 & Hotrina Saragih, S.Ag. & 65 & 85 & 95 \\
\hline 14 & Antonius Ofong, A.Ma & 50 & 60 & 75 \\
\hline 15 & Alfonsius Katkirik, S.Pd & 50 & 60 & 75 \\
\hline 16 & FX Minggu, S.Ag. & 50 & 65 & 80 \\
\hline 17 & Lusia Indawati, S.Ag. & 65 & 65 & 75 \\
\hline Jumlah Skor Total & 1035 & 1235 & 1410 \\
\hline Skor Maksimum Individu & 100 & 100 & 100 \\
\hline Skor Maksimum Kelompok & 1700 & 1700 & 1700 \\
\hline
\end{tabular}




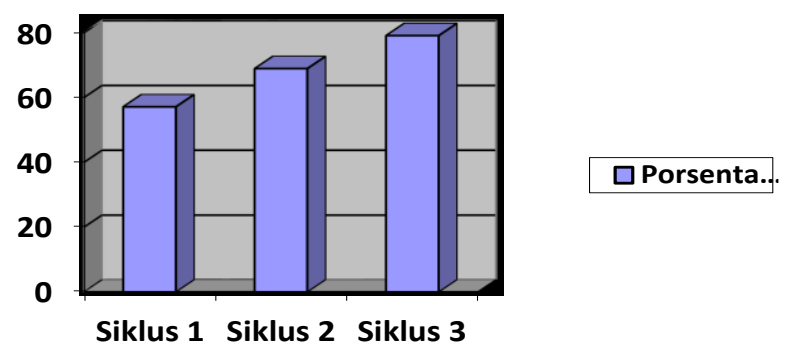

\section{Grafik 1. Ketuntasan Guru Pendidikan Agama Katolik}

Analisis data deskriptif kuantitatif

1) Pencapaian peningkatan kemampuan menyusun LKS pada guru agama Katolik setelah diberikan tindakan pada siklus I

$$
=\frac{1035}{1700} \times 100 \%=60,89 \%
$$

2) Pencapaian peningkatan kemampuan menyusun LKS pada guru pendidikan agama Katolik setelah diberikan tindakan pada siklus II:

$$
=\frac{1235}{1700} \times 100 \%=72,64 \%
$$

3) Pencapaian peningkatan kemampuan menyusun LKS pada guru pendidikan agama Katolik setelah diberikan tindakan pada siklus III:

$$
=\frac{1410}{1700} \times 100 \%=82,94 \%
$$

Dari hasil analisis data tersebut dapat disimpulkan bahwa:

a). Terjadi peningkatan kemampuan dalam menyusun LKS pada guru pendidikan agama Katolik setelah diberi pembinaan oleh pengawas melalui supervisi klinis. Hasil Peningkatan dapat diukur atau dilihat di sini adalah peningkatan prosentasi dari $60,89 \%$ pada siklus I ke prosentasi 72, 64\% pada siklus II sebesar $11,75 \%$

b). Terjadi peningkatan kemampuan pada guru pendidikan agama Katolik setelah diberi pembinaan oleh pengawas melalui supervisi klinis. Hasil Peningkatan dapat diukur atau dilihat di sini adalah peningkatan prosentasi dari $72,64 \%$ pada siklus II ke prosentasi 82,94 pada siklus III sebesar $10,3 \%$

c). Rata-rata kemampuan guru pendidikan agama Katolik sebelum diberi pembinaan 22,05 $\%$ naik menjadi $100 \%$.

Berdasarkan pembinaan yang telah dilakukan oleh pengawas pendidikan agama Katolik kepada guru-guru pendidikan agama Katolik melalui supervisi klinis maka, hasil observasi dapat disimpulkan sebagai berikut:

a) Pertemuan pertama kegiatan pembinaan belum menunjukkan hasil yang signifikan karena para guru belum terlalu semangat untuk ikut berpatisipasi secara penuh.

b) Pertemuan pertama kegiatan pembinaan belum menunjukkan hasil yang signifikan karena para guru belum memahami dan menguasai langkah-langkah penyusunan LKS.

c) Pembinaan yang dilakukan oleh pengawas melalui supervisi klinis demi meningkatkan profesionalisme guru pendidikan agma Katolik belum maksimal, sehingga belum membuahkan hasil yang maksimal. 
d) Proses pembinaan oleh pengawas menggunakan supervisi klinis baru pertama kali dilaksanakan sehingga para guru merasa kaku dalam menerapkannya.

e) Setelah adanya penjelasan lebih terperinci tentang manfaat pembinaan melalui supervisi klinis oleh pengawas, para guru menjadi paham sehingga pada proses kedua dan ketiga suasananya telah berubah ke arah yang lebih positif di mana semua guru ikut berpartisipasi secara aktif dalam mengikuti pembinaan.

Penelitian ini telah mencapai hasil akhir. Semua proses, langkah-langkah, metode dan lain-lain telah dilaksanakan dengan baik dan maksimal. Maka penelitian ini menyimpulkan bahwa pembinaan melalui supervisi klinis efektif untuk meningkatkan kemampuan guru dalam mengembangkan bahan ajar Lembar Kerja Siswa (LKS). Adapun tujuan penelitian ini adalah untuk meningkatkan kemampuan guru pendidikan agama Katolik dalam menyusun dan mengembangkan bahan ajar lembar kerja siswa (LKS). Tujuan ini telah tercapai. Bukti ketercapaian tersebut dapat dilihat dalam tabel-tabel analisis perkembangan kemampuan guru setiap siklus. Pada siklus I, prosentasi peningkatan keterampilan dan kemampuan guruguru pendidikan agama Katolik mencapai 60,89\%. Pada siklus II, prosentasi peningkatan kemampuan guru pendidikan agama Katolik menyusun LKS mencapai 72, 64\%, dan pada siklus III, prosentasi peningkatan kemampuan guru pendidikan agama Katolik mencapai $82,94 \%$. Kerja sama yang harmonis antara pengawas dan guru pendidikan agama Katolik dalam proses pelaksanaan supervisi klinis ini nampak sangat jelas. Semuanya bermuara pada tujuan akhir dari penelitian tindakan kepengawasan ini yang pada hakikatnya adalah untuk meningkatkan profesionalisme guru pendidikan agama Katolik dalam menyusun dan mengembangkan bahan ajar demi menjamin mutu pendidikan agama Katolik pada sekolahsekolah yang dibinanya. Dari analisis data di atas dapat disimpulkan bahwa pembinaan guru melalui supervisi klinis oleh pengawas efektif diterapkan dalam meningkatkan profesionalisme guru pendidikan agama Katolik di wilayah kota Mataram. Oleh karena itu, maka pembinaan guru melalui supervisi klinis harus terus dilaksanakan secara berkelanjutan, sebagaimana diatur dalam Permen Diknas Nomor 16 tahun 2007 tentang Standar Kualifikasi Akademik dan Kompetensi Guru untuk bersama berupaya meningkatkan profesionalisme guru. Adapun hasil penelitian ini sejalan dengan penelitian Islamuddin (2021) dan Wahyuni (2021) yang menjelaskan bahwa profesionalisme guru dapat ditingkatkan melalui supervisi klinis yang berkelanjutan oleh pengawas.

\section{Kesimpulan}

Berdasarkan hasil penelitian ini maka dapat ditarik beberapa kesimpulan sebagai berikut: (1) Pembinaan oleh pengawas dalam upaya meningkatkan profesionalisme guru pendidikan agama Katolik dalam mengembangkan bahan ajar penyusunan Lembar Kerja Siswa (LKS) melalui supervisi klinis menunjukkan peningkatan yang signifikan pada setiap siklus. (2) Aktifitas dalam setiap pembinaan menunjukkan bahwa semua guru pendidikan agama Katolik dapat meningkat profesionalismenya dalam setiap aspek. (3) Pembinaan guru pendidikan agama Katolik oleh pengawas melalui supervisi klinis dapat meningkatkan profesionalismenya pada setiap siklus. (4) Para guru menyadari bahwa pembinaan melalui supervisi klinis dapat membantu mereka untuk meningkatkan kemampuan dan skill mereka dalam mengembangkan bahan ajar penyusunan Lembar Kerja Siswa (LKS).

\section{Saran}

Adapun saran yang dapat disampaikan berdasarkan hasil penelitian ini adalah sebagai berikut; (1) Pembinaan guru oleh pengawas melalui supervisi klinis perlu direncanakan 
secara matang, (bukan datang begitu saja), juga perlu pengalokasian waktu dan pemilihan konsep yang sesuai. (2) Para guru harus selalu ada kesediaan untuk memperoleh pengetahuan dan informasi yang baru. (3) Para guru harus selalu menumbuhkan minat dan gairah terhadap tugas mengajar karena tugas mengajar sudah menyatu dengan hidupnya.

\section{Daftar Pustaka}

Agung Iskandar, dkk (2014). Mengembangkan profesionalitas guru, Upaya meningkatkan Profesionalisme Kinerja Guru, Jakarta: Bee Media Pustaka.

Arikunto Suharsimi (2014). Prosedur Penelitian (cet.15), Jakarta: Rineka Cipta.

Azhari Ahmad (2003). Supervisi Rencana Program Pemblajaran, Jakarta: Rian Putra.

Habeahan Salman (2007). Butir-butir Pendidikan Nilai Memasuki Abad 21, Bekasi: Krisna Mitra Pustaka.

Islamuddin, I. (2021). Supervisi Klinik sebagai Upaya Meningkatkan Kemampuan Guru dalam Mengelola Pembelajaran di SMA Negeri 8 Gowa. Jurnal Paedagogy, 8(4), 482-489. doi:https://doi.org/10.33394/jp.v8i4.4013

Kamaruddin, H. (2021). Upaya Meningkatkan Kompetensi Guru SMK Negeri 4 Gowa dalam Melaksanakan Proses Pembelajaran di Kelas Melalui Program Supervisi. Jurnal Paedagogy, 8(3), 414-421. doi:https://doi.org/10.33394/jp.v8i3.3894

Makawimbang Jerry H. (2013). Supervisi Klinis, Teori dan Pengukurannya, Bandung: Alfabeta.

Mujtahid (2011). Pengembangan Profesi Guru, Malang: UIN MALIKI Press.

Pidarta Made (2009). Supervisi Pendidikan Kontekstual, Jakarta: Rineka Cipta.

Purnamaraya, S. (2019). Upaya Meningkatkan Kompetensi Guru Kelas dalam Proses Pembelajaran Berdasarkan Kurikulum 2013 Melalui Supervisi Akademik di SD $\begin{array}{llll}\text { Negeri } & 45 & \text { Mataram. Jurnal Paedagogy, } & 6(2),\end{array}$ doi:https://doi.org/10.33394/jp.v6i2.2531

Ramayulis (2013). Profesi dan Etika Keguruan, Jakarta: Kalam Mulia.

Rusman (2014). Seri Manajemen Sekolah bermutu, Model-Model Pembelajaran, Mengembangkan Profesionalisme Guru (cet. ii), Jakarta: Rajawali.

Sagala Syaiful (2012). Supervsi Pembelajaran, Dalam Profesi Pendidikan, Bandung: Alfabet.

Sahertian Piet. A. (2010). Konsep Dasar dan Teknik Supervisi Pendidikan, Jakarta: Rineka Cipta.

Sudiarti, D. (2017). Upaya Meningkatkan Kompetensi Guru Kelas dalam Proses Pembelajaran Melalui Supervisi Akademik di SDN 9 Cakranegara. Jurnal Kependidikan: Jurnal Hasil Penelitian dan Kajian Kepustakaan di Bidang Pendidikan, Pengajaran dan Pembelajaran, 3(1). doi:https://doi.org/10.33394/jk.v3i1.463

Wahyuni, T. (2021). Supervisi Klinis oleh Kepala Sekolah guna Meningkatkan Kompetensi Guru dalam Mengelola Administrasi Kelas di SD Negeri 42 Ampenan. Jurnal Paedagogy, 8(2), 264-270. doi:https://doi.org/10.33394/jp.v8i2.3561

Zainudin, Z. (2016). Meningkatkan Kompetensi Guru Sasaran dalam Proses Pembelajaran Melalui Supervisi Akademik di SMPN 21 Mataram. Jurnal Kependidikan: Jurnal Hasil Penelitian dan Kajian Kepustakaan di Bidang Pendidikan, Pengajaran dan Pembelajaran, 2(1). doi:https://doi.org/10.33394/jk.v2i1.451 